\title{
Variabilitas Tangga Nada Talempong Pacik Dalam Konteks Kesenian Tradisi Minangkabau
}

\author{
Wimbrayardi ${ }^{1}$, Bambang Parmadi ${ }^{2}$ \\ ${ }^{1}$ Sendratsik FBS, Universitas Negeri Padang, Air Tawar, Padang, Indonesia, ${ }^{2}$ FKIP Universitas Bengkulu, Jl. \\ WR. Supratman, Kota Bengkulu, Indonesia \\ 'wimbrayardi@gmail.com,2bparmadie@unib.ac.id
}

Dalam musik tradisional Minangkabau khususnya musik Talempong Pacik, tidak ada kesamaan tangga nada antar kelompok musik Talempong di setiap kanagarian di Minangkabau. Tangga nada yang digunakan dalam Talempong tradisional tidak sama dengan tangga musik barat (diatonis) dengan kata lain tangga nada yang dipakai adalah pentatonis. Bagi masyarakat Minangkabau untuk memainkan Talempong Pacik, yang dibutuhkan adalah kebenaran oral rasa musik dalam menafsirkan suara atau nada yang diinginkan (sense of music). Hal tersebut, menjadikan bentuk variabilitas nada ataupun tangga nada tradisi Talempong Pacik menjadi sangat beragam. Dalam konteks kesenian tradisi bentuk tangga nada atau pola musik Talempong Pacik berbeda-beda, sehingga menjadikan kesenian tradisi ini sebagai kearifan lokal dengan warna varian tradisi dalam sosiokultur masyarakat pada beberapa kanagarian di Minangkabau. Berdasarkan pada teori etnomusikologi, kesenian tradisi khususnya musik mempunyai peran penting pada sosiokultur masyarakat pendukungnya, baik secara penggunan (use) maupun fungsinya (function).

Kata kunci: variabilitas, tangganada, talempong pacik

\section{Variability Of Talempong Pacik Scale In The Context Of The Minangkabau Traditional Art}

In Minangkabau traditional music, especially the Talempong Pacik music, there is no similarity in the scale of the Talempong music groups in each Kanagarian in Minangkabau. The scale used in traditional Talempong is not the same as the western (diatonic) music scale, in other words, the scale used is pentatonic. For the Minangkabau people to play Talempong Pacik, what is needed is the oral truth of the taste of music in interpreting the desired sound or tone (sense of music). This makes the variability of the tone or scale of the Talempong Pacik tradition very diverse. In the context of traditional arts, the musical forms of Talempong Pacik are different, making this traditional art a local wisdom art with traditional variant colors in socioculture in some Kanagarians in Minangkabau. Based on the ethnomusicology theory, traditional arts, especially music, have an important role in the socioculture of the supporting community, both in terms of use and function.

Keywords: variability, scale, talempong pacik

Proses Review : 1 - 20 Mei 2021, Dinyatakan Lolos: 31 Mei 2021 


\section{PENDAHULUAN}

Minangkabau dalam setiap melaksanakan berbagai jenis upacara adat dan peristiwa budaya dimeriahkan dengan menyajikan berbagai jenis seni pertunjukan. Adapun bentuk kesenian yang ditampilkan bervariasi dan mempunyai corak yang berbeda antara satu dengan lainnya. Hal ini tercermin dalam kehidupan social budaya masyarakatnya, adapun jenis-jenis seni pertunjukan tersebut adalah, seni gerak (tari), seni bunyi, Seni rupa, dan seni gabungan antara vocal dan musik, hal ini sejalan dengan pendapat Naim dalam Martarosa (2019: 89) menyatakan bahwa pada hakikatnya berbagai corak dan ragam kebudayaan Nusantara yang masih ada, dan sudah berkembang. Kebudayaan tersebut merupakan modal bagi pengembangan budaya selanjutnya, yang berguna bagi kesinambungan kebudayaannya.

Budaya Minangkabau juga melahirkan banyak jenis alat musik dan lagu. Di antara alat musik khas Minangkabau adalah alat musik tiup yang terdiri dari saluang, bansi, pupuik batang padi, sarunai, pupuik tanduak. Alat musik pukul yang terdiri dari Talempong, canang, tambur, rabano, indang, gandang, adok dan Alat musik gesek yaitu rabab. Alat musik ini biasanya dimainkan dalam pesta adat dan perkawinan.

Pada umumnya masyarakat Minangkabau memiliki kesenian musik tradisional Talempong Pacik. Musik Talempong Pacik merupakan salah satu kesenian kearifan budaya lokal yang terdapat di Minangkabau. Musik ini termasuk klasifikasi musik tradisi berbentuk ensambel.. Dalam konteks kesenian kearifan lokal, Talempong Pacik berkembang sebagai hasil karya seni budaya yang diwariskan secara turun temurun dari generasi kegenerasi oleh masyarakat pendukungnya.

Istilah TalempongPacik yang dikenal sekarang ini hanya merupakan perkataan yang bersifat umum yang dipakai untuk keperluan ilmiah. Perkataan ini digunakan untuk menunjukkan sesuatu genre music tradisional Talempong yang memiliki teknik permainan interlocking sehingga dapat membedakannya dengan konsep permainan genre music Talempong yang bersifat melodis yang dimainkan secara horizontal. Sungguhpun penggunaan istilah Talempong Pacik bermula untuk keperluan ilmiah, namun ternyata segi rasionalnya juga disadari oleh paramusisi dewasa ini sehingga istilah Talempong Pacik sudah berkembang dan diterima secara baik oleh semua lapisan masyarakat Minangkabau. Dengan demikian, secara impulsif para musisi dunia juga mengikuti istilah tersebut. Mengamati pengertian yang dikandungnya, ternyata istilah Talempong Pacik yang dipopulerkan ini cukup mempunyai landasan filosofis sosiokultur kearifan budaya lokal yang kuat dengan alasan-alasan sebagai berikut: 1) Istilah Talempong Pacik memiliki makna konseptual yang erat hubungannya dengan salah satu cara permainan dari genre musik Talempong yang dimainkan dengan cara memegang alat musik Talempong tersebut sebagai bagian alat music utama dalam ensambel Talempong tradisional, 2) Istilah Talempong Pacik lebih mempertegas pengertian konsepmusikal terhadap dua teknik permainan genre music Talempong yang hidup di Alam Minangkabau, yaitu genre music Talempong yang menggunakan teknik interlocking (TalempongPacik), dan genre music Talempong yang dimainkan secara melodis (Talempong Duduak). Kedua genre music Talempong ini sama-sama hadir sebagai ensambel musik tradisionaldi berbagai pelosok Minangkabau, 3) Istilah Talempong Pacik member pemahaman yang lebih jelas terhadap pengkajian dan penelitian aneka ragam musik Talempong yang ada di Minangkabau, sehingga dapat melahirkan informasi ilmiah yang berangkat dari klasifikasinya yang khas sesuai dengan konsep musical dari genre musik Talempong itu masing-masing.

Setiap permainan dipraktikkan oleh satu orang musisi yang memegang dua buah alat musik Talempong. Namun kadang-kadang musisi bagian Talempong jantan hanya memainkan satu buah Talempong, karena pemakaian jumlah alat musik Talempong selalu disesuaikan dengan keperluan gua-gua yang dimainkan. Ketiga permainan Talempong itulah yang dipraktikkan dengan teknik interlocking, melahirkan suatu komposisi musik spesifik Talempong Pacik yang termasuk salah satu musik tradisional primadona masyarakat Minangkabau.

\section{METODE PENELITIAN}

Untuk mencapai tujuan penelitian, dalam penelitian ini digunakan pendekatan kualitatif, seperti yang dikemukakan oleh Moleong (2008:12) menyatakan bahwa penelitian kualitatif adalah penelitian yang menghasilkan data deskriptif, yaitu berupa kata-kata dan tindakan dari orang-orang dan prilaku yang diamati sebagai data utama, data kedua berupa data tambahan yang berasal dari studi kepustakaan. Selanjutnya Moleong (2008:2) mengatakan: hasil fenomena yang diamati tidak berupa angka-angka tetapi koefisien hubungan antara variabel data yang berupa kata-kata atau gambaran.

Metode deskriptif analisis digunakan untuk meneliti status kelompok manusia atau suatu objek, suatu kondisi, suatu sistem pemikiran dan suatu peristiwa pada masa sekarang. Tujuan penelitian deskriptif adalah mendiskripsikan secara akurat mengenai faktor-faktor dan sifat-sifat serta hubungan antara fenomena yang diselidiki. Dengan demikian penelitian kualitatif perlu melihat, meninjau, dan mengumpulkan informasi dan kemudian mengungkapkan serta menjabarkan secara tepat yang diteliti.

\section{ANALISIS DAN INTEPRETASI DATA}

\section{Ciri Nada Pada Talempong}

Berdasarkan teori perbandingan panjang pendeknya dawai 
(monochord) suatu alat yang mempunyai satu dawai, menemukan empat macam nada berdasarkan empat perbandingan, perbandingan itu adalah: $1: 1=$ nada dasar, $2: 1=$ oktaf, $3: 1=$ kwint, $4: 3=$ kwart, dengan telah ditemukannya kwint ini, maka tangga nada diatonis c-d-ef-g-a-b-c, dapat dibentuk berdasarkan rentetan dari tujuh kwint yaitu: f-c-g-d-a-e-b.

Apa yang ditemukan pada teori perbandingan ini jelas merupakan nada dari sejumlah yang bersifat ilmu pasti dalam membandingkan jarak anda dari sejumlah nada. Jarak nada itu telah melahirkan suatu bentuk tangga nada dengan sistem dan kaidah tertentu yang merupakan jati dirinya sendiri. Ini dapat dilihat bahwa bagian yang satu turut menentukan bagian yang lain, misalnya satu bagian kwint dapat membentuk bagian nada lainnya berdasarkan perbandingan tertentu, keseluruhan bagian itu akhirnya membentuk suatu sistem tangga nada sebagaimana sistem tangga nada Yunanni secara teoritis ditemukan oleh Phytagoras berdasarkan teori perbandingan itu.

Berdasarkan teori Phytagoras dalam Alexander John Ellis dapat kita lihat apa yang terdapat pada nada-nada Talempong yang menjadi dasar bangunan musik tradisional. Dalam hal ini penggunaan teori tersebut digunakan pula konsep cent yang dikemukakan oleh Alexander John Ellis dalam prosedingnya untuk menghitung jarak antara nada yang satu dengan nada yang lain. Ia membagi tingga nada diatonis yang berjarak sama seperti yang terdapat pada piano adalah Oktaf $=1200 \varnothing$ (cents) tiap nada setengah $($ semitone $)=100 \phi$, maka interval nada $\mathrm{c}-\mathrm{cis}=100 \phi$, dan interval nada $\mathrm{c}-\mathrm{d}=200 \varnothing$ dan sebagainya.

Sebagai contoh kasus dapat dilihat nada-nada Talempong Pacik di Padang Magek yang telah diukur oleh Boestanoel Arifin Adam, nada-nada itu adalah:

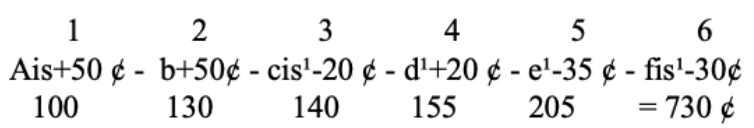

Apabila dilihat nada-nada Talempong ini berdasarkan perbandingan kwint yaitu $3 / 2$, maka kwint dari ais +50 adalah $\mathrm{f}+50$, yang berjarak $702 \propto$. Berdasarkan teori Phytagoras atau $700 £$ menurut sistem nada diatonis. Pada nada-nada Talempong tersebut tidak ditemui nada yang muncul sebagai perbandingan $3 / 2$ dari nada dasar ais +50 ф. Selanjutnya apabila dilihat perbandingan $4 / 3$ yang memunculkan kwart, maka kwart dari ais $+50 \varnothing$ adalah dis $+50 \propto$ yang berjarak $498 \propto$, berdasarkan teori Phytagoras atau $500 \notin$ menurut sistem nada diatonis. Nada kwart dari ais $+50 \varnothing$ ini tidak ditemui pada nada-nada Talempong tersebut. Maka deretan nada-nada Talempong itu bukanlah terlahir berdasarkan azas-azas perbandingan menurut ilmu pasti.

Berdasarkan gejala akustik yang pertama kali digunakan untuk teori musik oleh Jean Philippe Rameau dalam

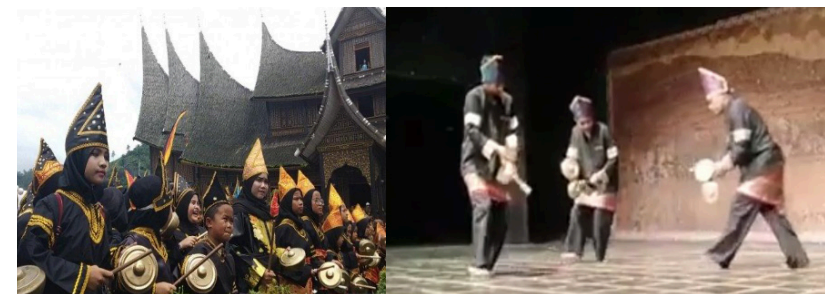

Gambar 1. Antraksi Talempong Pacik pada masyarakat Minangkabau

(Sumber: Wim. 2019)

karyanya "Traite de L'harmonic sebagaimana disebut Philip Gossett (1970) pada penelitiannya mejelaskan; ....... all high sounds are contained in low ones, but low ones, coversely, are not contained in high ones. Berdasarkan teori tersebut maka lahirlah teori overtone series berdasarkan hukum akustik yang demikian, ternyata deretan nada-nada yang terdapat pada Talempong itu, bukanlah merupakan nada-nada yang muncul berdasarkan nada Talempong yang lebih tinggi tidak terdapat pada nada Talempong yang rendah adalah ais $+50 \phi$, sedangkan nada ini tidak ada dalam deretan nada-nada Talempong.

Talempong yang ada pada beberapa kelompok di daerah lain di Minangkabau yang kecendrungannya tidak sama, maka nada-nada tersebut bukanlah wujud dari suatu hukum, baik berdasarkan perbandingan maupun secara akustik. Hal yang demikian menunjukkan bahwa wujud dari deretan nada-nada Talempong yang berbeda itu bukanlah pelahiran dari suatu sistem, yakni sistem tangga nada yang merupakan ukuran nilai estetika, yang utama bagi masyarakat Minangkabau untuk pondasi bangunan musik mereka. Kalaulah kelahiran dari rentetan nada-nada itu bukanlah pelahiran dari suatu sistem, maka jelaslah bahwa rentetan nada yang berbeda itu terlahir sebagai kehendak untuk memenuhi kebutuhan adanya nada-nada yang berbeda, sebab untuk menciptakan musik sangat memerlukan sejumlah nada yang berbeda.

Persoalan satu kesatuan dalam suatu sistem tangga nada dari masing-masing alat tersebut, tidak jadi persoalan serius bagi mereka. Mereka tidak menghendaki secara teoritis, bahwa nada gong harus sama dengan nada Talempong tertentu, atau pupuik sarunai yang dimainkan harus selaras dengan Talempong dan sebagainya. Meskipun kenyataan demikian, yakni maasing-masing alat berbeda nada dan tidak dalam keselarasan, akan tetapi kesatuan permainan musik yang terlahir melalui alat-alat tersebut dapat mereka nikmati, dan musik tersebut tidak cacat bagi mereka, itulah musik mereka.

\section{Frekwensi Nada Pada Kelompok Talempong}

Pengukuran nada Talempong Pacik ini berpedoman kepada standart nada diatonis yang menggunakan untuk menentukan satuan frekwensi nada dan memakai Cents dalam mengukur satuan jarak atau interval nadanya. Dalam menentukan wilayah nada (posisi oktaf) dari 


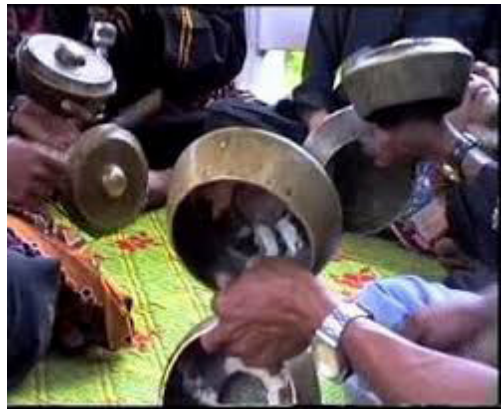

Gambar 2. Talempong Pacik Minangkabau Sumatera Barat (Sumber: Wim. 2019)

nada-nada Talempong Ateh Guguak, adalah mengmbil pedoman kepada sistem pengorganisasian tingkatan bunyi yang lazim di pakai di Amerika, yaitu The USA standarts Association (USA STD). Wilayah okatf sampai wilayah oktaf, wilayah oktaf netral berada pada posisi dilihat pada Fig. Dengan demikian frekwensi nada Talempong tradisional kelompokn Ateh Guguak ini adalah:

Nada $1=+3 \mathrm{~Hz}=466.16+3=469.16 \mathrm{~Hz}$

Nada $2=+8 \mathrm{~Hz}=523.25+8=531.25 \mathrm{~Hz}$

Nada $3=\mathrm{D} 5+2 \mathrm{~Hz}=587.33+2=589.33 \mathrm{~Hz}$

Nada $4=$ E5 $-10 \mathrm{~Hz}=659.26-10=649.26 \mathrm{~Hz}$

Nada $5=$ F5 $+5 \mathrm{~Hz}=698.46+5=703.46 \mathrm{~Hz}$

Nada $6=\mathrm{F} 5+12 \mathrm{~Hz}=698.46+12=710.46 \mathrm{~Hz}$

Jadi frekwensi nada-nadanya adalah:

Ais $=469.16 \mathrm{~Hz}, \mathbf{C}=531.25 \mathrm{~Hz}, \mathbf{D}=589.33 \mathrm{~Hz}$, E $\quad=649.26 \mathrm{~Hz}, \mathbf{F}=703.46 \mathrm{~Hz}, \mathbf{F}=710.46 \mathrm{~Hz}$

Masalah interval nada dipedomani dari teori Alexander J Ellis (1926) yang menemukan sistem cent untuk menentukan satuan interval nada, nada Talempong Pacik ini juga diukur intervalnya dengan bantuan chromatic tuner dengan hasil dibawah ini:

\begin{tabular}{|c|c|c|c|}
\hline Nada & 1 & $=$ Ais & +10 cent \\
\hline Nada & 2 & $=\mathrm{C}$ & +30 cent \\
\hline Nada & 3 & $=\mathrm{D}$ & +8 cent \\
\hline Nada & 4 & $=\mathrm{E}$ & $+40 \mathrm{c}$ \\
\hline Nada & 5 & $=\mathrm{F}$ & +20 \\
\hline Nada & 6 & $=\mathrm{F}$ & $+50 \mathrm{ce}$ \\
\hline
\end{tabular}

Dengan demikian didapatkan interval nada-nada Talempong Pacik pada kelompok Ateh Guguak sebagai berikut:

Ais $-\mathrm{C}=200-10+30=220$ cent

C $-\mathrm{D}=200-30+8=178$ cent

$\mathrm{D}-\mathrm{E}=200-8+40=152 \mathrm{cent}$

$\mathrm{E}-\mathrm{F}=100+40+20=160 \mathrm{cent}$

$\mathrm{F}-\mathrm{F}=50-20=30 \mathrm{cent}$

Kemudian Talempong Pacik Nagari Labuah Gunuang, untuk mengetahui nada Talempong itu digunakan alat pengukur chromatic tuner yang didasarkan pada standart ukuran nada-nada diatonis, dan dari pengukuran dengan alat tersebut diperoleh data sebagai berikut:

\begin{tabular}{|c|c|c|}
\hline Nada & 1 & $=\mathrm{G}+10$ cent \\
\hline Nada & 2 & $=$ Ais -30 cent \\
\hline Nada & 3 & $=\mathrm{B}+10$ cent \\
\hline Nada & 4 & $=\mathrm{Cis}-10$ cent \\
\hline Nada & 5 & $=$ Dis -35 cent \\
\hline Nada & 6 & $=\mathrm{E}-10$ cent \\
\hline
\end{tabular}

Dari pengukuran Talempong Pacik itu, dapat digambarkan jarak antara nada pertama dengan nada lainnya seperti dibawah ini:

Jarak nada 1 dengan nada 2 atau $\mathrm{G}+10$ ke Cis $-30=$ 140 cent

Jarak nada 2 dengan nada 3 atau Cis -30 ke B $+10=$ 100 cent

Jarak nada 3 dengan nada 4 atau $G+10$ ke Cis $-10=$ 100 cent

Jarak nada 4 dengan nada 5 atau Cis -10 ke Dis $+35=$ 95 cent

Jarak nada 5 dengan nada 6 atau Dis -35 ke E $-10=$ 85 cent

Data pengukuran Talempong Pacik di atas, dapat digambarkan jarak antara nada pertama dengan nada selanjutnya nada kedua.

Jarak nada pertama dengan nada kedua $\left(a^{1}+15\right.$ cent ke $\mathrm{b}^{1}-15$ cent) sama dengan 185 cent

Jarak nada kedua dengan nada ke tiga $\left(b^{1}-15\right.$ cent ke $\left.c^{2}\right)$ sama dengan 115 cent

Jarak nada keempat ke nada kelima $\left(\mathrm{d}^{2}+25\right.$ cent ke dis ${ }^{2}+$ 20 cent) sama dengan 95 cent

Jarak nada kelima ke nada enam $\left(\mathrm{dis}^{2}+20\right.$ cent ke $\mathrm{e}^{2}-5$ cent) sama dengan 95 cent

Dari hasil perhitungan di atas dapat dilihat pada skema tangga nada secara keseluruhan seperti berikut ini:

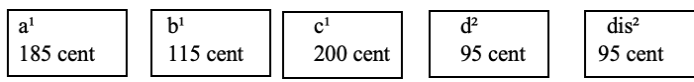

\section{SIMPULAN}

Berdasarkan hasil pengukuran dari penelitian talempong dapat ditarik simpulan sebagai berikut; Talempong Pacik merupakan kesenian tradisional Minangkabau dimana susunan tangga nada atau nada-nada setiap daerah mempunyai frekwensi dan karakter musical yang berbeda, sesuai dengan kebutuhan dimana talempong itu tumbuh dalam kehidupan masyarakatnya. Terkait dengam simpulan tersebut, disarankan agar dimasa mendatang perlu diadakan kajian lebih mendalam terhadap nada-nada talempong yang ada di Minangkabau secara kelompok. 


\section{DAFTAR RUJUKAN}

Arikunto, Suharsimi. 2002. Prosedur Penelitian, Suatu Pendekatan Praktek. Jakarta: PT. Asri Mahasatya.

Bahar, Mahdi. 1997. Adakah Sistem Tangga Nada Talempong Musik Tradisional Minangkabau. Padang Panjang: ASKI Padang Panjang

Ellis, Alexander John 1926. The Musical Times and Singing Class Circular. Jurnal The Musical Times, Vol. 67, No. 1000. London UK: Musical Times Publications Ltd.

2009. Illustrations of Just and Tempered Intonation, Publication Proceedings of the Musical Association. London UK: Routledge Heriot-Watt University

Gossett, Philip. 1970. Observations sur notre instinct pour la musique by Jean-Philippe Rameau. Jurnal Music Library Association, Second Series, Vol. 26, No. 3. MiddleTown, Inggris: Musical Times Publications Ltd

Kayam, umar. 1981. Seni Tradisi Masyarakat. Jakarta: Penerbit SinarHarapan

Moleong, Lexy J. 2008. Metodologi Penelitian Kualitatif. Bandung: PT. Remaja Rosdakarya Bandung.

Martarosa, M., Yakin, I., \& Fernando, K. (2019). Kesenian Ronggeng Pasaman Dalam Perspektif Kreativitas Apropriasi Musikal. Mudra Jurnal Seni Budaya, 34(1), 8796. https://doi.org/10.31091/mudra.v34i1.642

Muslim. 1989. Proses Pembuatan Talempong di Sungai Puar Kecamatan Banuhampu Kabupaten Agam; Suatu Tinjauan Organologis. Padang Panjang: ASKI Padang Panjang

Syailendra. 2000. Musik Tradisi. Padang:UNP Padang

\section{UCAPAN TERIMAKASIH / PENGHARGAAN}

Rasa syukur di haturkan kepada Allah SWT Tuhan Yang Maha Esa. Ucapan terima kasih dan rasa hormat penulis ucapkan kepada Jurusan Sendratasik UNP Padang dan FKIP Universitas Bengkulu, LPPM UNP Padang dan Universitas Bengkulu, para informan, pelaku seni tradisi, Tim Peneliti, Bli Eka jurnal ISI Denpasar, MUDRA ISI Denpasar, dan pihak-pihak yang tidak dapat penulis sebutkan. Dengan bantuan segala hal dan fasilitas yang diberikan kepada penulis sampai akhirnya penulis dapat menyelesaikan penelitian ini. Tidak dipungkiri penelitian ini masih belum sempurna, tentunya pada waktu yang akan datang dapat memperdalam penelitian ini serta dapat dilanjutkan dengan peneliti-peneliti lainnya. 